\title{
Thermogravimetric analysis for characterization of the pellets produced with different forest and agricultural residues
}

\section{Martha Andreia Brand ${ }^{*} \odot$ Ricardo Ritter de Souza Barnasky ${ }^{2}$ Carolina Alves Carvalho C $^{2}$ Rodrigo Buss ${ }^{2}$ (-) Deyvis Borges Waltrick ${ }^{2}+$ Rodolfo Cardoso Jacinto $^{3}$}

${ }^{1}$ Departamento de Engenharia Florestal, Centro de Ciências Agroveterinárias (CAV), Universidade do Estado de Santa Catarina (UDESC), 88520-000, Lages, SC, Brasil. E-mail: martha.brand@udesc.br. *Corresponding author

${ }^{2}$ Programa de Pós-graduação em Engenharia Florestal, Centro de Ciências Agroveterinárias (CAV), Universidade do Estado de Santa Catarina (UDESC), Lages, SC, Brasil.

${ }^{3}$ Centro de Ciências Agroveterinárias, Universidade do Estado de Santa Catarina (UDESC), Lages, SC, Brasil.

ABSTRACT: The pelleting of forest and agricultural materials, mainly because many residues from both industries can be used in this process, has been an alternative in obtaining added value products to energy generation. Thus, the aim of this study was to evaluate the energy quality of the pellets produced from forest and agricultural residues as raw materials and to verify the utility of the thermogravimetric analysis (TGA) and the differential thermogravimetric analysis (DTG) in characterizing the behavior of the pellets during the combustion process. Four residues were used: (1) Pinus spp. woodchips, (2) apple pruning residues, (3) aciculated dry branches of Araucaria angustifolia and (4) A. angustifolia empty-seeds. Chemical composition of the raw materials was determined and the physical and energetic properties of the pellets were analysed. Plus, the proximate analysis of the pellets was carried out. The samples were submitted to TGA with a heating rate of $20^{\circ} \mathrm{C}$ min ${ }^{-1}$ from room temperature to $1000^{\circ} \mathrm{C}$, in a $\mathrm{N}_{2}$ atmosphere. The variation of chemical composition of each residue was determinant in the characterization of each stage of the thermal degradation. Stages and events of the degradation were closely linked to the chemical and energetic nature of the samples. Use of TGA to characterize the thermal degradation of the pellets produced with different forest and agricultural residues was demonstrated as an efficient technique to quantify and qualify the events that occurred in each stage of the combustion of these biofuels. Key words: $T G A, D T G$, thermal degradation, residues.

Análise termogravimétrica para caracterização dos pellets produzidos com diferentes resíduos florestais e agrícolas

RESUMO: A peletização de resíduos florestais e agrícolas tem sido uma alternativa na obtenção de produtos com maior valor agregado para a geração de energia, pois muitos resíduos podem ser utilizados neste processo. Assim, o objetivo deste estudo foi avaliar a qualidade energética dos pellets produzidos com residuos florestais e agrícolas como matéria-prima e verificar a viabilidade de uso da análise termogravimétrica (TGA) e análise termogravimétrica diferencial (DTG) para caracterizar o comportamento dos pellets durante o processo de combustão. Foram utilizados quatro resíduos: (1) partículas de Pinus spp., (2) resíduos de poda de maçã. (3) ramos secos aciculados de Araucaria angustifolia $e$ (4) falhas de pinhão de A. angustifolia. Foram determinadas a composição química das matérias-primas e analisadas suas propriedades fisicas e energéticas, bem como a análise imediata dos pellets. As amostras foram submetidas ao TGA com uma taxa de aquecimento de $20^{\circ} \mathrm{C}$ min-1 da temperatura ambiente a $1000^{\circ} \mathrm{C}$, em atmosfera de $\mathrm{N2}$. As curvas termogravimétricas permitiram a avaliação da perda de massa em função da temperatura. O DTG permitiu a avaliação da taxa de perda de massa. A variação na composição química de cada resíduo foi determinante para caracterizar cada estágio da degradação térmica. Os estágios e os eventos de degradação estavam intimamente ligados à natureza química e energética das amostras. O uso de TGA, para caracterizar a degradação térmica dos pellets produzidos com diferentes resíduos florestais e agricolas, se mostrou eficiente para quantificar e qualificar os eventos que ocorreram em cada estágio de combustão desses biocombustiveis.

Palavras-chave: $T G A, D T G$, degradação térmica, resíduos.

\section{INTRODUCTION}

The southern region of Brazil concentrates the largest areas of Pinus plantations of the country, comprising about $88 \%$ of the total. Only the states of Santa Catarina and Parana have
$34 \%$ and $42 \%$ of the 1.6 million hectares cultivated, with the production focused on multiple uses (IBÁ, 2016). Among the industries attended by the forest sector, cellulose, kraft paper, panels and sawmills prevailed (ACR, 2015). These fields constitute an important source of raw materials to these products 
and have had an increasing demand over the years (KRONKA et al., 2005).

Brazilian wood-based industries produce about 41 million tons of residues annually (ABRAF, 2013). Wood residues can be defined as the waste or leftovers that remain after mechanical, physical or chemical processes and are not incorporated to the final product (QUIRINO, 2004). They are generically classified as barks, woodchips, sawdust and ashes produced in the process.

The use of wood residues has been studied to be applied in the production of agglomerated panels. However, the residue requires to be cleaned and needs proper sawmills. Therefore, energy generation using different processes of conversion may be another application for these leftovers (FAGUNDES, 2003). Currently, the timber industry incinerates these wastes in order to generate thermal or electric energy that can be applied to the production process. Thus, this renewable source of energy is now a reality in the productive sector and is also able to replace the use of fossil fuels. In this context, the biomass is established as a clean and renewable source of energy (VASCONCELLOS, 2002).

In addition to planted Pinus, the vegetation of the region is composed naturally by the Araucaria moist forest and it is part of the Atlantic Forest biome. Araucaria angustifolia (Bert.) O. Kuntze is the most common species of the forest. It belongs to the Araucariaceae family and it is the only species that occurs naturally in Brazil (MANTOVANI et al., 2004).

The most important products and uses of Araucaria emerged from its exploitation in the past. Sawing wood, energetic uses, panels, paper, pulp and cellulose are some examples. The dry branches and rejects can be used as firewood or boiler fuel and the pine nuts can be served as food for men and animals (GUERRA et al., 2002). Due to logging restrictions, the wood exploitation is prohibited and the uses are associated to the harvesting of the pine nuts for family consumption and trade (SILVA; REIS, 2009), and the production of firewood from the branches (GUERRA et al., 2002). Considering the social aspects of the region, the production of pine nuts is a significant economic activity, which involves the participation of entire families. It can be considered the most important activity for family farming because it is the main source of annual income of those families (NETO et al., 2010).

Nevertheless, the pine nut is only one of the components of the female strobili of the Araucaria. On average, $41.8 \%$ of the fresh weight of the strobilus consists of the seeds, $50.7 \%$ of the empty-seeds and $7.5 \%$ of its central axis (MANTOVANI et al., 2004).

The aciculated dry branches are thin and needle-shaped secondary tree branches of the Araucaria angustifolia. The evaluation of the annual deposition of litter in 17-year-old stands of $A$. angustifolia showed that it can reach 6.96 Mg.ha ${ }^{-1}$ and it is composed of branches $(26,3 \%)$ and needles (73.7\%) (SCHUMACHER et al., 2004). Biomass production after clear cutting of a 27-year-old stand of Araucaria angustifolia was quantified as $51.5 \%$ of wood, $14.7 \%$ of bark, $13 \%$ of roots, $11.8 \%$ of live branches, $6.6 \%$ of aciculated branches and $0.5 \%$ of dead branches (SCHUMACHER et al., 2011). The aciculated dry branches naturally drop off the plants and they may become a phytosanitary issue for the animals if they are not collected. These branches have been reported in the lungs of cattle and horses that graze around $A$. angustifolia forests. The branches may cause bronchopneumonia, respiratory difficult, coughing, progressive slimmer, limited swallowing, nasal ulcer and hyperthermia. The foreign body aspiration is not reported frequently; although, the aspiration of the aciculated dry branches was one of the main causes of death due to respiratory difficulties of the cattle in the Araucaria moist forest region in Santa Catarina (EVANGELISTA et al., 2014).

In this context, $A$. angustifolia has the potential to supply forest biomass for energy production through the use of residues of the pine nut production chain (empty-seeds) and the use of the aciculated dry branches from self-pruning.

Beyond the forest based industry, the fruticulture has a significant economic importance to the Santa Catarina state. Brazil has 33,583 hectares of apple orchard. The South region has $98.74 \%$ of these plantations and 16,364 hectares of these orchards are located in the state. In 2017, southern Brazil was responsible for $94.10 \%$ of the national apple production. Santa Catarina is the largest national producer, contributing with $52.46 \%$ of the annual production (IBGE, 2017).

At the end of the fruit harvesting, the orchards of apple (Malus domestica) require annual and cyclical procedures. These procedures produced biomass materials, such as branches, trunks and rootstocks (BOSCHIERO et al., 2016), generating a significant quantity of residues that have to be discarded (SPINELLI \& PICCHI, 2010). Most of these residues are burned at the own orchards (SAN JOSÉ et al, 2014), being a waste of biomass resources (MAGAGNOTTI et al., 2013). 
Thus, finding uses for these leftovers should allow the conversion of a disposal problem into an additional production, with potential to revenues or cost reduction for managing the solid residues of the production (SPINELLI \& PICCHI, 2010).

The energetic use of the described forest and agricultural residues may be a desirable and economically viable environmental alternative for the destination of such materials. Among the energetic conversion processes, the pelleting is highlighted. This technique is based on biomass densification through heat and pressure application, which raises the specific mass and decreases the product moisture, increasing the energy density of the fuel, compared to its raw materials (NONES et al., 2017). Considering the quantity, the location, the availability and the raw materials' energy quality, the cited products may have potential for the production of the pellets for energy generation.

Thermogravimetric analysis (TGA) is an alternative that can be applied to determine the energy quality of the materials. The TGA can quantitatively solve complex mixtures due to the thermal decomposition of each component (BARNETOet al., 2009). In lignocellulosic materials, the combination of TGA and differential thermogravimetric analysis (DTG) allows to obtain the lignin content (GHETTI et al, 1996) and its influence during the combustion process because the lignin plays a critical role in the use of biomass to energetic purposes (FENGEL; WEGENER, 1989). It can also be used as a method for analyzing natural fuels (DIMITRAKOPOULOS, 2001).

Thus, this study aimed to evaluate of the energetic quality of the pellets made from forest and agricultural residues as raw materials, in order to verify the viability of using TGA and DTG to characterize the behavior of these pellets through the combustion process.

\section{MATERIALS AND METHODS}

Residues used in this study were Pinus spp. woodchips, branches from the pruning of apple trees, Araucaria angustifolia aciculated branches and nonfertilized nuts (empty-seeds). They were provided by a door factory in Lages, Santa Catarina (27 48 $57^{\prime \prime} \mathrm{S}$, $\left.50^{\circ} 19^{\prime} 33^{\prime \prime} \mathrm{W}\right)$, a company located in Urubici, Santa Catarina ( $\left.28^{\circ} 0^{\prime} 54^{\prime \prime} \mathrm{S}, 49^{\circ} 35^{\prime} 31^{\prime \prime} \mathrm{W}\right)$, and farmers in the region of Lages, respectively. All residues were collected in 2016.

A total of $200 \mathrm{~kg}$ of each material was collected to do the pelleting and the analyses. A fraction of the biomass in natura was ground in a Willey mill for chemical analyses. The particle size was between 40 and 60 mesh. The total extractives and lignin content in natura were determined by TAPPI T264 and TAPPI T222 standards and the holocellulose was determined by difference.

Pellets were produced in a pilot laboratory machine with flat matrix and pelleting capacity of $400 \mathrm{~kg} \mathrm{~h}^{-1}$. The pellets were cooled in a controlled chamber with $65 \%$ of relative humidity and at $22^{\circ} \mathrm{C}$ for 24 hours. After that, the moisture content was determined according to EN 14774 standards, the gross calorific value and net calorific value were measured using the standard DIN 51900 and the proximate analysis was determined in a thermogravimetric scale, based on the ASTM 1762 standards.

The thermogravimetric analysis was undertaken with the purpose of determining the behavior of the pellets during combustion in a complete combustion system that is used for the production of thermal energy. The TGA analysis was carried out using the TGA 2000 (Automatic Multiple Sample Thermogravimetric Analyzer by NAVAS Instruments). Each sample unit presented similar weight (1g) and four replicates for each kind of pellet (Pinus spp. woodchips, Araucaria angustifolia aciculated dry branches, non-fertilized nuts (emptyseeds)). Mass and the volume of each sample were determined. The moisture content was analyzed before the thermogravimetric analysis, according to EN 14774 standards.

For each of the sample units, the test was done in an inert atmosphere of $\mathrm{N}_{2}$ with a flow rate of $93,75 \mathrm{~mL} \mathrm{~min}{ }^{-1}$. The heating rate was $20^{\circ} \mathrm{C} \mathrm{min}{ }^{-1}$, starting from room temperature to $1000^{\circ} \mathrm{C}$. When the equipment reached $1000^{\circ} \mathrm{C}$, the test was carried out until the mass loss stabilized.

TG curves were obtained in order to measure the mass loss as a function of temperature and DTG curves allowed to evaluate the mass loss rate. The data of chemical and physical analyses were submitted to the Scott-Knott test at $95 \%$ of significance. The mean values and the standard deviation of the variables were also presented.

\section{RESULTS AND DISCUSSION}

\subsection{Physical and energetic characterization of the pellets and the in natura biomass}

Regarding to the chemical composition of the residues, the $A$. angustifolia aciculated dry branches had the highest content of the total extractives (Table 1). All residues were statistically 
Table 1 - Chemical characterization of different forest and agricultural residues in natura.

\begin{tabular}{lccc}
\hline Residues & TEC (\%) & L (\%) & H (\%) \\
\hline Pinus woodchips & $10.09 \mathrm{c}$ & $26.01 \mathrm{c}$ & $73.99 \mathrm{a}$ \\
Apple pruning & $13.72 \mathrm{~b}$ & $29.26 \mathrm{~b}$ & $70.74 \mathrm{~b}$ \\
A. angustifolia aciculated dry branches & $19.95 \mathrm{a}$ & $42.16 \mathrm{a}$ & $57.84 \mathrm{c}$ \\
A. angustifolia empty-seeds & $7.55 \mathrm{~d}$ & $41.91 \mathrm{a}$ & $58.09 \mathrm{c}$ \\
Mean & 12,83 & 34.90 & 65.10 \\
SD $(\%)$ & 5,21 & 3.31 & 1.78 \\
\hline
\end{tabular}

Note: TEC $=$ total extractives content, $\mathrm{L}=$ acid insoluble lignin content, $\mathrm{H}=$ holocellulose content, $\mathrm{SD}=$ standard deviation. Means followed by the same letters in the same column did not differ significantly $(\mathrm{P}<0.005)$ by the Scott-Knott test.

different and the lowest content was observed for the empty-seeds. Values reorted for Pinus were above the extractive contents reported in the literature, from $5 \%$ to $8 \%$ (GARCIA et al., 2016) and $6 \%$ (MAZIERO et al., 2014).

The lignin content of the aciculated dry branches and the empty-seeds were statistically similar, they presented the highest values. This may be explained by the origin of these materials. The empty-seeds are part of the A. angustifolia female strobili and the aciculated dry branches are the secondary parts of the A. angustifolia branches, composed of wood, bark tree and needles. The result was similar to the ones reported in the literature concerning the Pinus trees (GARCIA et al., 2016; MAZIERO et al., 2014).

The highest amount of holocellulose was observed for the Pinus residues. The empty-seeds and the aciculated dry branches showed the lowest values. They were statistically equal and inversely proportional to the lignin content.

The chemical characterization of the solid residues of Pinus found $12.6 \%$ of the extractives in water, $23.6 \%$ of lignin and $60.6 \%$ of holocellulose (BIANCHI et al., 2010). Both lignin and holocellulose contents reported in this study were higher than the ones found by BIANCHI et al. (2010).

According to BIANCHI et al. (2010) and BERGHEL et al. (2013), the lignin and the extractive contents of the biomass are essential to the links and the packing of particles during the pelleting process. However, BRADFIELD \& LEVI (1984) point out that they are only essential below a threshold value of $34 \%$ in wood sample.

JACINTO et al. (2017), using different mixing proportions of empty-seeds of $A$. angustifolia and Pinus to produce pellets, and the authors in this study observed that the higher the amount of lignin was the higher was the amount of moisture content needed in order to produce better quality pellets.

Considering the pelleting production, the authors observed that the Pinus residue was the easiest one to pellet, which can be explained by the fact that this residue showed a total amount of lignin and extractives of around $36 \%$. The other analyzed residues were harder to pellet because of the higher amount of lignin and extractives in the samples; therefore, the moisture content needed for linking and packing the particles during the pelleting process was higher.

The proximate analysis determines the burning behavior of the fuel (Table 2). The fixed carbon represents the quantity of mass that burns in the solid form, while the volatile content indicates the fuel mass that will burn in the gaseous form. Besides that, the ashes content determines the amount of residues left after the completed combustion process.

Regarding the fixed carbon content of the pellets, the empty-seed residue showed the highest value and the apple pruning one presented the lowest. Results for the aciculated dry branches and the Pinus were statistically equal. The analysis reported higher results when compared to the fixed carbon content found for similar pellets of Pinus in the literature (RAMOS E PAULA et al., 2011).

The Pinus and the apple pruning pellets presented the highest volatile matter values and did not differ statistically from each other, while the aciculated dry branches and the empty seed pellets were statistically different, presenting the lowest values. The matter loss of the Pinus and the apple pruning pellets during the thermogravimetric analysis were influenced by the highest amount of volatile matter. Both of the residues had the highest accumulated matter losses on the Stage II (Tables 4 and 5). It is during the Stage II that the burning of the volatile compounds of the fuels happens. 
Table 2 - Physical and energetic properties of the pellets.

\begin{tabular}{|c|c|c|c|c|c|c|}
\hline Pellet & $\mathrm{MC}^{*}$ & $\mathrm{FC}(\%)$ & VM (\%) & $\mathrm{A}(\%)$ & GCV (kcal kg $\left.{ }^{-1}\right)$ & $\mathrm{NCV}\left(\mathrm{kcal} \mathrm{kg}^{-1}\right)$ \\
\hline Pinus woodchips & $9.94 \mathrm{~b}$ & $22.28 \mathrm{~b}$ & $76.85 \mathrm{a}$ & $0.87 \mathrm{~b}$ & $4704 \mathrm{~b}$ & 3884 a \\
\hline Apple pruning & $10.47 \mathrm{~b}$ & $19.10 \mathrm{c}$ & $78.62 \mathrm{a}$ & $2.27 \mathrm{a}$ & $4526 \mathrm{~b}$ & 3699 a \\
\hline A. angustifolia aciculated dry branches & $11.84 \mathrm{a}$ & $21.85 \mathrm{~b}$ & $74.91 \mathrm{~b}$ & $3.24 \mathrm{a}$ & 5065 a & $4108 \mathrm{a}$ \\
\hline A. angustifolia empty-seeds & $8.09 \mathrm{c}$ & $26.31 \mathrm{a}$ & $71.05 \mathrm{c}$ & $2.64 \mathrm{a}$ & $4668 \mathrm{~b}$ & 3944 a \\
\hline Mean & 10.09 & 22.38 & 75.36 & 2.07 & 4740 & 3909 \\
\hline $\mathrm{SD}(\%)$ & 7.08 & 4.92 & 1.62 & 26.05 & 2.35 & 269 \\
\hline
\end{tabular}

Note: $\mathrm{MC}=$ moisture content $\mathrm{FC}=$ fixed carbon, $\mathrm{VM}=$ volatile matter, $\mathrm{A}=$ ash, $\mathrm{GCV}=$ gross calorific value, $\mathrm{NCV}=$ net calorific value ${ }^{*}$ The moisture content was measured after cooling and conditioning the pellets for 24 hours after the pelleting process. Values followed by the same letters in the same column did not differ significantly $(\mathrm{P}<0.005)$ by the Scott-Knott test.

The highest ash content was found in the aciculated dry branches, but the numbers did not differ statistically from the apple pruning and the empty-seed pellets. The dry branches also had highlights in the gross calorific value, while the other samples did not differ statistically.

The gross calorific values were close tothe ones found inliterature for similar studies with Pinus pellets (DIMITRAKOPOULOS, 2001; JACINTO et al., 2017). Relating to the net calorific value, all results were statistically similar. It can be explained by the fact that the NCV is the useful energy available for the energy generation system and the pellet with the biggest GCV was the same that showed the highest moisture content, while the samples with the lowest moisture contents had the lowest GCV, resulting in similar net calorific values.

The lignin and extractives are the compounds that release more energy from wood samples (TILLMAN et al., 1981). Therefore, the values reported for the aciculated dry branches are consistent with the higher lignin and the extractive contents reported for this biomass (Table 1 and Table 2).
Mean values of mass and volume of the pellets analyzed on TGA did not present variations between them (Table 3). Both mass and volume of the samples were homogeneous. Thus, it is expected that the variation of the behavior of the pellets during the thermogravimetric analysis is due to the composition of the samples.

The moisture content of the Pinus and the apple pruning samples did not differ statistically. The empty-seed samples had the lowest moisture content while the aciculated dry branches presented the highest values. The density of the empty-seed pellets was higher than the density of the other samples and they also did not differ statistically.

\subsection{Thermogravimetric analysis}

The TGA and DTG curves of the Pinus pellets (Figure 1A) showed that there was no significant mass loss until the temperature reached approximately $200^{\circ} \mathrm{C}$. After this temperature, a slight mass loss occurred while the temperature was raising up to $380^{\circ} \mathrm{C}$. As evidenced by the DTG curve, between $380^{\circ} \mathrm{C}$ and $450^{\circ} \mathrm{C}$ a fast mass loss was observed. The mass loss is attenuated between

Table 3 - Pellets properties before TGA analysis.

\begin{tabular}{|c|c|c|c|c|c|c|c|c|}
\hline \multirow{2}{*}{$\begin{array}{l}\text { Pellet } \\
\text { Pinus woodchips }\end{array}$} & \multicolumn{2}{|c|}{ Moisture content $(\%)^{*}$} & \multicolumn{2}{|c|}{ Mass (g) } & \multicolumn{2}{|c|}{ Volume $\left(\mathrm{cm}^{3}\right)$} & \multicolumn{2}{|c|}{ Density $\left(\mathrm{g} \cdot \mathrm{cm}^{-3}\right)$} \\
\hline & 8.25 & $\mathrm{~b}$ & 0.798 & $\mathrm{a}$ & 0.000725 & $\mathrm{a}$ & 1.103 & $\mathrm{~b}$ \\
\hline Apple pruning & 8.10 & $\mathrm{~b}$ & 0.819 & $\mathrm{a}$ & 0.000787 & $\mathrm{a}$ & 1.040 & $\mathrm{~b}$ \\
\hline A. angustifolia aciculated dry branches & 10.95 & $\mathrm{a}$ & 0.820 & $\mathrm{a}$ & 0.000767 & $\mathrm{a}$ & 1.071 & $\mathrm{~b}$ \\
\hline A. angustifolia empty-seeds & 7.10 & $\mathrm{c}$ & 0.837 & a & 0.000702 & $\mathrm{a}$ & 1.193 & a \\
\hline Mean & \multicolumn{2}{|c|}{8.10} & \multicolumn{2}{|c|}{0.819} & \multicolumn{2}{|c|}{0.000745} & \multicolumn{2}{|c|}{1.102} \\
\hline $\mathrm{SD}(\%)$ & \multicolumn{2}{|c|}{5.81} & \multicolumn{2}{|c|}{5.88} & \multicolumn{2}{|l|}{6.62} & \multicolumn{2}{|c|}{3.47} \\
\hline
\end{tabular}

Values followed by the same letters in the same column did not differ significantly $(\mathrm{P}<0.005)$ by the Scott-Knott test. ${ }^{*}$ Moisture content was measured before the TGA analysis. 

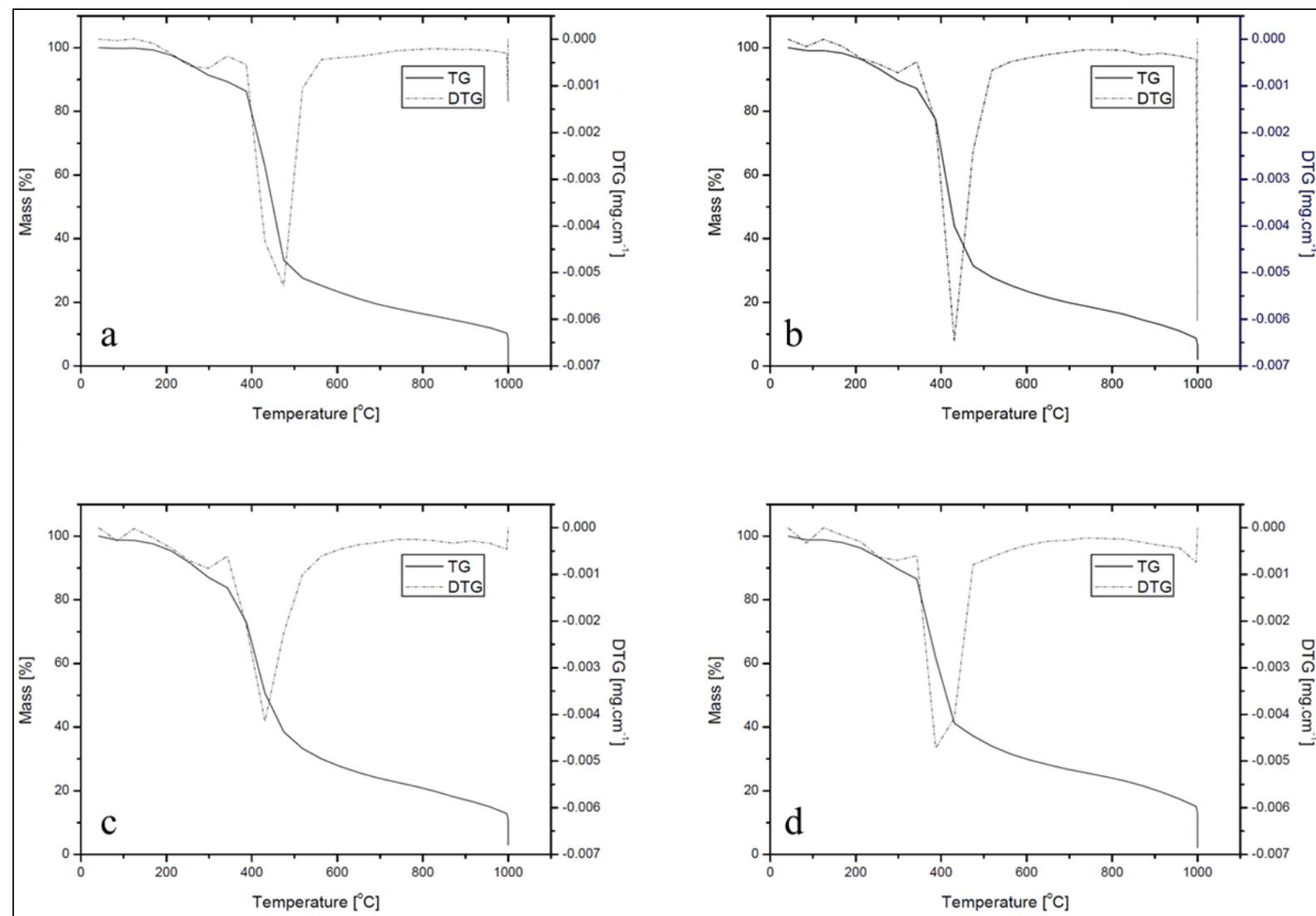

Figure 1 - Thermogravimetric curves (TG) and Derivative thermogravimetric curves (DTG) of analyzed pellets samples. (a) Pinus, (b) apple pruning, (c) A. angustifolia dry branches and (d) A. angustifolia empty-seeds.

$450^{\circ} \mathrm{C}$ and $500^{\circ} \mathrm{C}$. The sample mass decreased in a constant rate after $500^{\circ} \mathrm{C}$ and, from $500^{\circ} \mathrm{C}$ to $1000^{\circ} \mathrm{C}$, its complete degradation happened.

For the apple pruning pellets (Figure 1B), a slight mass loss is observed at temperatures up to $200^{\circ} \mathrm{C}$, followed by an increasing rate until $350^{\circ} \mathrm{C}$. After $350^{\circ} \mathrm{C}$, a fast mass loss was observed until approximately $550^{\circ} \mathrm{C}$. Between $550^{\circ} \mathrm{C}$ and $1000^{\circ} \mathrm{C}$ the mass loss rate decreased and the complete degradation occurred at $1000^{\circ} \mathrm{C}$.

The TG and the DTG curve analysis of the A. angustifolia aciculated dry branch pellets (Figure 1C) showed a slight mass loss rate untill the temperature reached approximately $200^{\circ} \mathrm{C}$, followed by a small increase at temperatures lower than $300^{\circ} \mathrm{C}$. Between $300^{\circ} \mathrm{C}$ and $500^{\circ} \mathrm{C}$ a fast and substantial mass loss came about and was only attenuated at the temperatures from $500^{\circ} \mathrm{C}$ to $1000^{\circ} \mathrm{C}$.

Results for the empty-seed pellets (Figure 1D) showed that the mass loss initiated at room temperature followed by a slight increase between $100^{\circ} \mathrm{C}$ and $200^{\circ} \mathrm{C}$. Within the range of $200^{\circ} \mathrm{C}$ and $380^{\circ} \mathrm{C}$ a higher increase was observed. Then, it was between $380^{\circ} \mathrm{C}$ and $450^{\circ} \mathrm{C}$ that the highest mass loss rate was verified. After $450^{\circ} \mathrm{C}$, the pellets decreased its mass loss rate until the complete degradation at $1000^{\circ} \mathrm{C}$.

The differences in the chemical composition of the biomass (Table 1) determined the variance incombustion behavior of the pellets, since the lignin, the extractives and the holocellulose have different ranges of combustion and can have their degradation on different periods during the combustion process. Therefore, the differences in chemical composition of the biomass influenced the burning behavior of the pellets under combustion.

The temperature ranges and the accumulated mass loss are presented in table 4 .

TGA curves of the pellets may be divided in three main stages. Stage I (drying), Stage II (active pyrolysis) and Stage III (passive pyrolysis) 
Table 4 - Temperature ranges and accumulated mass loss for each pellet.

\begin{tabular}{|c|c|c|}
\hline Pellets & Temperature range $\left({ }^{\circ} \mathrm{C}\right)$ & Accumulated mass loss $(\%)$ \\
\hline & $25-200$ & 0.69 \\
\hline & $200-380$ & 12.00 \\
\hline \multirow[t]{6}{*}{ Pinus woodchips } & $400-450$ & 68.00 \\
\hline & $450-500$ & 72.00 \\
\hline & $500-1000$ & 91.50 \\
\hline & Reminiscent mass at $1000^{\circ} \mathrm{C}$ & 0.40 \\
\hline & $25-100$ & 0.88 \\
\hline & $100-350$ & 12.00 \\
\hline \multirow[t]{5}{*}{ Apple pruning } & $350-550$ & 75.00 \\
\hline & $550-1000$ & 93.40 \\
\hline & Reminiscent mass at $1000^{\circ} \mathrm{C}$ & 2.26 \\
\hline & $25-200$ & 1.30 \\
\hline & $200-300$ & 49.18 \\
\hline \multirow[t]{5}{*}{ A. angustifolia aciculated dry branches } & $300-500$ & 64.00 \\
\hline & $600-1000$ & 89.00 \\
\hline & Reminiscent mass at $1000^{\circ} \mathrm{C}$ & 3.14 \\
\hline & $25-100$ & 1.15 \\
\hline & $100-200$ & 3.74 \\
\hline \multirow[t]{4}{*}{ A. angustifolia empty-seeds } & $200-380$ & 38.17 \\
\hline & $380-450$ & 62.75 \\
\hline & $450-1000$ & 87.00 \\
\hline & Reminiscent mass at $1000^{\circ} \mathrm{C}$ & 2.27 \\
\hline
\end{tabular}

(NYAKUMAet al., 2016). Applying the same definitions, the curve results are presented in table 5 .

The Stage I involve the volatilization of low weight compounds and adsorbed water (RAMOS E PAULA et al., 2011). For all the analyzed pellets, the highest loss rates occurred at Stage II, which is the stage when the degradation of hemicelluloses, cellulose and lignin happen. At the Stage III, the mass loss is attributed to the remaining lignin from Stage II. The lignin degradation occurs in a slower gradual rate than the other compounds. This behavior was better observed in the dry branch and empty-seed pellets. They had higher lignin content, lost a lower proportion of mass at the Stages I and II and had a slow degradation of remaining mass at Stage III.

Although, the temperature ranges of the degradation of wood compounds have specific temperatures, it is highlighted that, in inert atmospheres, a separation of individual events is not observed, but an overlap of events is more common (BIANCHI et al., 2010), as evidenced by the TGA curves.

TGA can be determinant to relate the chemical analysis to the mass loss. The thermo gravimetric technique has been used to determine the composition of lignocellulosic materials with satisfying results (CARRIER et al., 2011).

Thermogravimetric studies of lignocellulosic biomass indicated characteristic temperature ranges of the degradation of lignin, with a slow rate between $250^{\circ} \mathrm{C}$ and $750^{\circ} \mathrm{C}$, hemicelluloses, starting at $250^{\circ} \mathrm{C}$ until $500^{\circ} \mathrm{C}$, and cellulose, with a fast degradation starting at $375^{\circ} \mathrm{C}$ (LOPEZ-GONZALEZ et al., 2013).

Even though the pellets analyzed by the TGA have similar curves, through the DTG analysis different peaks of temperature were observed and the maximum mass loss rate was verified. The maximum loss rate for the empty-seed pellets was at $380^{\circ} \mathrm{C}$. The Pinus pellets had the maximum rate at $480^{\circ} \mathrm{C}$ and for the apple pruning and the dry branch 
Table 5 - Thermogravimetric stages of the pellets.

\begin{tabular}{llll}
\hline Sample & Stage I & Stage II & Stage III \\
\hline Pinus waste wood & $25^{\circ} \mathrm{C}$ to $300^{\circ} \mathrm{C}$ & $300^{\circ} \mathrm{C}$ to $500^{\circ} \mathrm{C}$ & $500^{\circ} \mathrm{C}$ to $1000^{\circ} \mathrm{C}$ \\
\hline Apple prunning & $25^{\circ} \mathrm{C}$ to $350^{\circ} \mathrm{C}$ & $350^{\circ} \mathrm{C}$ to $550^{\circ} \mathrm{C}$ & $550^{\circ} \mathrm{C}$ to $1000^{\circ} \mathrm{C}$ \\
\hline Dry Branches of Araucaria angustifloia & $25^{\circ} \mathrm{C}$ to $350^{\circ} \mathrm{C}$ & $350^{\circ} \mathrm{C}$ to $500^{\circ} \mathrm{C}$ & $500^{\circ} \mathrm{C}$ to $1000^{\circ} \mathrm{C}$ \\
\hline Empty-seeds of Araucaria angustifolia female strobiles & $25^{\circ} \mathrm{C}$ to $380^{\circ} \mathrm{C}$ & $380^{\circ} \mathrm{C}$ to $500^{\circ} \mathrm{C}$ & $500^{\circ} \mathrm{C}$ to $1000^{\circ} \mathrm{C}$ \\
\hline
\end{tabular}

samples the maximum rate was observed at $430^{\circ} \mathrm{C}$. However, the apple pruning pellets showed a higher rate than the dry branches.

The change of these ranges may be explained by the chemical composition of the biomass (Table 1). Samples of dry branches showed the highest lignin content and the lowest cellulose content. The lignin quantity contributes to reduce the rate of the degradation of the sample, decreasing the DTG peak of the sample as well. The higher contents of lignin in the empty-seed and the aciculated dry branch pellets also brings to a better thermal stability of the samples, that had about $10 \%$ and $12 \%$ of its initial mass when the TGA reached $1000^{\circ} \mathrm{C}$, before the complete stabilization of mass loss at the same temperature.

Comparing to the Pinus pellets, the other samples showed a higher thermal stability until $500^{\circ} \mathrm{C}$. However, above $500^{\circ} \mathrm{C}$ the Pinus lost more mass in relation to the other pellets. It occurs because the initial combustion of other pellets may form other compounds which are more stable in the thermal degradation process. This event contributes to initiate the combustion at lower temperatures but with slower rates, producing compounds that decrease the combustion process at high temperatures (BIANCHI et al., 2010).

All samples presented small DTG peaks at $100^{\circ} \mathrm{C}$, mainly related to water loss, with the highest rate to the empty-seed pellets and the lowest rate to the Pinus samples. In the range up to $350^{\circ} \mathrm{C}$, a higher mass loss rate related to the aciculated dry branch sample was observed, followed by the empty-seed, apple pruning and Pinus pellets. The lignin contents influenced the beginning of the pyrolysis.

Relating the TGA results (Figure 1 and Table 4) and the ash contents (Table 2), it was observed that the results of reminiscent mass were consistent to the results obtained through the proximate analysis.

A direct relationship between the fixed carbon and the change in the TG and DTG curves was observed. The empty-seeds presented the highest fixed carbon content and the highest mass loss rate at lower temperatures than the other samples. The apple pruning presented the lowest fixed carbon value, and the highest mass loss rate was observed at higher temperatures. At $450^{\circ} \mathrm{C}$ the aciculate dry branch pellets also presented the highest peak of DTG, but with the lowest depth, when compared to the other samples. This can be explained because the aciculated dry branch samples presented the highest quantities of the extractives and lignin. A relation between the mass loss rate peaks of the DTG and the contents of the extractives can be observed, with the empty-seed pellet having the highest DTG peak and the lowest extractive content.

\section{CONCLUSION}

In terms of energy quality, the $A$. angustifolia aciculated dry branch pellets showed the highest energetic potential and a slower and better distributed combustion throughout the burning process, when compared to the other pellets. A similar behavior was observed for the A. angustifolia emptyseed pellets. The apple pruning pellets presented the lowest energetic potential.

The usage of thermogravimetric analysis to characterize the thermal degradation of the pellets produced using different forest and agricultural residues is shown as an efficient technique to quantify and qualify the events occurred in each stage of the combustion of these biofuels. The thermal degradation rate and heating values of the pellets were influenced by the contents of volatile matter, fixed carbon and lignin.

Thermal decomposition of the pellets occurred at three main stages. Stage I (drying), Stage II (active pyrolysis) and Stage III (passive pyrolysis), with the temperature varying according to each material analysed. For all pellets, the highest mass loss rate occurred at Stage II. The mass loss at Stage III was attributed to the reminiscent lignin from Stage II, which occurred in a lower and gradual rate.

The variation of the chemical composition of the residues was essential to characterize each stage of the thermal degradation. Stages and events 
of pyrolysis were closely linked to the chemical and energetic nature of the raw materials.

\section{ACKNOWLEDGEMENTS}

The authors acknowledge Dr. Enéas Ricardo Konzen for the valuable suggestions and Gisele Paim Ribeiro Domingues Lopes for the technical support with the analyses.

Funding: This reseach was supported by the Fundação de Amparo à Pesquisa do Estado de Santa Catarina (FAPESC) and the Fundo de Apoio à Manutenção e ao Desenvolvimento da Educação Superior (FUMDES) through scholarships.

\section{DECLARATION OF CONFLICTING INTERESTS}

The authors declared no potential conflicts of interest with respect to the research, authorship, and/or publication of this article.

\section{AUTHORS' CONTRIBUTIONS}

All authors contributed equally for the conception and writing of the manuscript. All authors critically revised the manuscript and approved of the final version.

\section{REFERENCES}

ABRAF. Anuário estatístico ABRAF 2013 ano base 2012. Brasília: [s.n.], 2013. Available from: <http://www.ipef.br/estatisticas/ relatorios/anuario-abraf13-br.pdf>. Accessed: Sep. 24, 2017.

ACR. Anuário estatístico de Base Florestal para o Estado de Santa Catarina 2016: ano base 2015. [S.1.]: [s.n.], 2016. Available from: $\quad<$ http://www.acr.org.br/download/biblioteca/ACR 2016. pdf $>$. Accessed: Sep. 30, 2017

BARNETO, A. G. et al. Effects of the composting and the heating rate on biomass gasification. Energy and Fuels, 2009. v. 23, n. 2 , p. 951-957. Available from: <https://pubs.acs.org/doi/pdf/10.1021/ ef8005806>. Accessed: Oct. 10, 2017. doi: 10.1021/ef8005806.

BERGHEL, J. et al. The effects of kraft lignin additives on wood fuel pellet quality, energy use and shelf life. Fuel Processing Technology, 2013. v. 112, p. 64-69. Available from: <https:// www.sciencedirect.com/science/article/pii/S0378382013000672>. Accessed: Oct. 10, 2017. doi: 10.1016/j.fuproc.2013.02.011.

BIANCHI, O. et al. Nonisothermal Degradation of Wood Using Thermogravimetric Measurements. Polímeros, 2010. v. 20, n. 5, p. 395-400. Available from: <http://www.revistapolimeros.org.br/ files/v20n5/v20n5a12.pdf>. Accessed: Oct. 17, 2017. doi: 10.1590/ S0104-14282010005000060.

BOSCHIERO, M. et al. Life cycle assessment of bioenergy production from orchards woody residues in Northern Italy. Journal of Cleaner Production, 2016. v. 112, p. 2569-2580. Available from: $<$ https://www.sciencedirect.com/science/ article/pii/S0959652615013220>. Accessed: Nov. 01, 2017. doi: 10.1016/j.jclepro.2015.09.094.

BRADFIELD, J.; LEVI, M. P. Effect of species and wood to bark ratio on pelleting of southern woods. For. Prod. J.,1984, v. 34, n.
1, p. 61-63. Available from: <https://www.cabdirect.org/cabdirect/ abstract/19840692450>. Accessed: Nov. 01, 2017.

CARRIER, M. et al. Thermogravimetric analysis as a new method to determine the lignocellulosic composition of biomass. Biomass and Bioenergy, 2011. v. 35, n. 1, p. 298-307. Available from: <http://linkinghub.elsevier.com/retrieve/pii/ S0961953410003314>. Accessed: Nov. 08, 2017. doi: 10.1016/j. biombioe.2010.08.067.

DIMITRAKOPOULOS, A. P. Thermogravimetric analysis of Mediterranean plant species. Journal of Analytical and Applied Pyrolysis, 2001. v. 60, n. 2, p. 123-130. Available from: <https:// www.sciencedirect.com/science/article/pii/S0165237000001649>. Accessed: Nov. 01, 2017. doi: 10.1016/S0165-2370(00)00164-9.

EVANGELISTA, C. et al."Grimpa" de Araucaria angustifolia como causa de morte por insuficiência respiratória em bovinos. VII Encontro Nacional de Diagnóstico Veterinário, 2014. Available from: $\quad<$ https://www2.ufrb.edu.br/apa/component/phocadownload/ category/8-miscelanea?download=112:6747>. Accessed: Oct. 21, 2017.

FAGUNDES, H. A. V. Diagnóstico da produção de madeira serrada e geração de resíduos do processamento de madeira de florestas plantadas no Rio Grande do Sul. [S.1.]: Universidade Federal do Rio Grande do Sul, 2003. Available from: $<$ http://hdl. handle.net/10183/4567>. Accessed: Dec. 03, 2017.

FENGEL, D.; WEGENER, G. Wood: chemistry, ultrastructure, reactions. [S.1.]: [s.n.], 1989.

GARCIA, D. P. et al. Decomposição térmica de pellets de madeira por TGA. Holos, 2016. v. 1, n. 32, p. 327-339. Available from: <http://www2.ifrn.edu.br/ojs/index.php/HOLOS/ article/view/3886>. Accessed: Feb. 15, 2017. doi: 10.15628/ holos.2016.3886

GHETTI, P. et al. Thermal analysis of biomass and corresponding pyrolysis products. Fuel, 1996. v. 75, n. 5, p. 565-573. Available from: <https://s3.amazonaws.com/academia.edu. documents/46056837/Thermal analysis of biomass and correspo20160529-31893-1xcfpl1.pdf?AWSAccessKeyId=스IAI WOWYYGZ2Y53UL3A\&Expires $=1538509133 \&$ Signature $=1 \mathrm{cO}$ CdXDZ\%2B6JhXAp\%2BINr4pVkPch4\%3D\&response-contentdisposition=inline $\% 3 \mathrm{~B} \% 20$ filename $\% 3 \mathrm{DThermal}$ analysis_of biomass and correspo.pdf>. Accessed: Nov. 14, 2017.

GUERRA, M. P. et al. Exploração, manejo e conservação da araucária (Araucaria angustifolia). Sustentável Mata Atlântica: a exploração dos seus recursos florestais. São Paulo: SENAC, 2002, v. 1, p. 85-101.

IBÁ, B. T. I.-. Relatório anual - O setor brasileiro de árvores plantadas. [S.1.]: [s.n.], 2016. Available from: <http://iba.org/ pt/sala-de-imprensa/releases/9-conteudo-pt/715-iba-publicarelatorio-anual-2016>. Accessed: Sep. 24, 2017.

IBGE. Levantamento Sistemático da Produção Agrícola. [S.1.], 2017. Available from: $<$ https://sidra.ibge.gov.br/home/lspa/brasil $>$. Accessed: Oct. 10, 2017.

JACINTO, R. C. et al. Use of waste from the production chain of pinion for the production of pellets for energy generation. Floresta, 2017. v. 47, n. 3, p. 353-363. Available from: <https:// revistas.ufpr.br/floresta/article/view/52080>. Accessed: Dec. 15, 2017. doi: 10.5380/rf.v47i3.52080. 
KRONKA, F. J. N. et al. A cultura do pínus no Brasil. São Paulo: Sociedade Brasileira de Silvicultura, 2005.

LOPEZ-GONZALEZ, D. etal. Thermogravimetric-mass spectrometric analysis on combustion of lignocellulosic biomass. Bioresource Technology, 2013. v. 143, p. 562-574. Available from: <https:// www.sciencedirect.com/science/article/pii/S0960852413009711>. Accessed: Sep. 15, 2017. doi: 10.1016/j.biortech.2013.06.052.

MAGAGNOTTI, N. et al. Technology alternatives for tapping the pruning residue resource. Bioresource Technology, 2013. v. 128, p. 697-702. Available from: <https://www.sciencedirect. com/science/article/pii/S0960852412016586>. Accessed: Sep. 20, 2017. doi: 10.1016/j.biortech.2012.10.149.

MANTOVANI, A. et al. Reproductive phenology and seed production of Araucaria angustifolia (Bert.) O. Kuntze Revista Brasileira de Botânica, 2004. v. 27, n. 4, p. 787-796. Available from: <http://www. scielo.br/pdf/\%0D/rbb/v27n4/v27n4a17.pdf>. Accessed: Oct. 04, 2017.

MAZIERO, R. et al. Caracterização química dos resíduos de Pinus spp. para fabricação de compósitos plástico-madeira Cuiabá: [s.n.], 2014. Available from: <http://www.metallum.com. br/21cbecimat/CD/PDF/204-131.pdf>. Accessed: oct. 04, 2017. (Electronic publication)

NETO, J. F. et al. Projeto kayuvá: valorização do pinhão na agricultura familiar da serra catarinense. Cidadania em Ação: Revista de Extensão e Cultura, 2010. v. 4, n. 1. Available from: $<$ http://www.revistas.udesc.br/index.php/udescemacao/article/ view/1976>. Accessed: Oct. 10, 2017.

NONES, D. L. et al. Quantification of agricultural and forestry waste biomass to production of compacts for power generation. Revista de Ciências Agroveterinárias, 2017. v. 16, n. 2, p 155-164. Available from: <http://www.revistas.udesc.br/index. php/agroveterinaria/article/download/223811711622017155/pdf>. Accessed: Sep. 24, 2017. doi: 10.5965/223811711622017155.

NYAKUMA, B. B. et al. Thermogravimetric and kinetic analyses of oil palm empty fruit bunch (OPEFB) Pellets using the distributed activation energy model. Journal of Physical Science, 2016. v. 27, n. 3, p. 67-83. Available from: <https://www.researchgate.net/profile/ Bemgba_Nyakuma/publication/306106063_Thermogravimetric and_Kinetic_Analyses_of_Oil_Palm_Empty_Fruit_Bunch OPEFB_Pellets_Using_the_Distributed_Activation_Energy Model/links/5836753208aed45931c64e91/Thermogravimetric-andKinetic-Analyses-of-Oil-Palm-Empty-Fruit-Bunch-OPEFB-PelletsUsing-the-Distributed-Activation-Energy-Model.pdf $>$. Accessed: Sep. 20, 2017. doi: 10.21315/jps2016.27.3.5.
QUIRINO, W. F. Utilização energética de resíduos vegetais. 2004. Available from: <http://www.mundoflorestal.com.br/ arquivos/aproveitamento.pdf $>$. Accessed: Nov. 14, 2017.

RAMOS E PAULA, L. E. et al. Characterization of residues from plant biomass for use in energy generation. Cerne, 2011. v. 17, n. 2, p. 237-246. Available from: $<$ http://www.scielo.br/pdf/cerne/ v17n2/v17n2a12.pdf $>$. Accessed: Oct. 10, 2017. doi: 10.1590/ S0104-77602011000200012.

SAN JOSÉ, M. J. et al. Thermal exploitation of fruit tree pruning wastes in a novel conical spouted bed combustor. Chemical Engineering Journal, 2014. v. 238, p. 227-233. Available from: <https://www.sciencedirect.com/science/article/pii/ S1385894713012667>. Accessed: Oct. 10, 2017. doi: 10.1016/j. cej.2013.09.073.

SCHUMACHER, M. V. et al. LITTERFALL IN AN Araucaria angustifolia (Bertol.) Kuntze FOREST IN PINHAL GRANDE, RS. Revista Árvore, 2004. v. 28, n. 1, p. 29-37. Available from: $<$ http://www.scielo.br/pdf/rarv/v28n1/a05v28n1>. Accessed: Nov. 15, 2017. doi: 10.1590/S0100-67622004000100005.

SCHUMACHER, M. V. et al. BIOMASS PRODUCTION AFTER CLEAR CUTTING IN A 27-YEAR-OLD STAND OF Araucaria angustifolia (Bertol.) Kuntze IN QUEDAS DO IGUAÇU, PR. Ciência Florestal, 2011. v. 21, n. 1, p. 53-62. Available from: <http://www.scielo.br/scielo.php?pid=S198050982011000100053\&script $=$ sci_abstract\&tlng=pt $>$. Accessed: Nov. 15, 2017. doi: 10.5902/198050982747.

SILVA, C. V. DA; REIS, M. S. BRAZILIAN PINE NUTS' PRODUCTION IN CAÇADOR'S REGION, SC: ASPECTS OF THE ATTAINMENT AND ITS IMPORTANCE FOR LOCAL COMMUNITIES Ciência Florestal, 2009. v. 19, n. 4, p. 363 374. Available from: <http://www.scielo.br/pdf/cflo/v19n4/19805098-cflo-19-04-00363.pdf $>$. Accessed: Nov. 15, 2017. doi: $10.5902 / 19805098892$.

SPINELLI, R.; PICCHI, G. Industrial harvesting of olive tree pruning residue for energy biomass. Bioresource Technology, 2010. v. 101, n. 2, p. 730-735. Available from: <https://www. sciencedirect.com/science/article/pii/S0960852409010682>. Accessed: Nov. 15, 2017. doi: 10.1016/j.biortech.2009.08.039.

TILLMAN, D. A.; et al. Wood combustion: Principles, process and economics. LONGON: ACADEMIC PRESS INC, 1981.

VASCONCEllos, G. F. Biomassa - A Eterna Energia do Futuro. São Paulo: SENAC, 2002. 